\title{
Report
}

\section{Implication of Economic Partnership Agreements (EPAs) on Kenya}

\author{
Augustus Muluvi, Christopher Onyango, Manaseh Otieno, Simon Githuku
}

Kenya Institute for Public Policy Research and Analysis (KIPPRA), Nairobi, Kenya

\section{Email address:}

amuluvi@kippra.or.ke (A. Muluvi), conyango@kippra.or.ke (C. Onyango), motieno@kippra.or.ke (M. Otieno), sgithuku@kippra.or.ke (S. Githuku)

\section{To cite this article:}

Augustus Muluvi, Christopher Onyango, Manaseh Otieno, Simon Githuku. Implication of Economic Partnership Agreements (EPAs) on Kenya. Journal of World Economic Research. Vol. 5, No. 3, 2016, pp. 15-25. doi: 10.11648/j.jwer.20160503.11

Received: July 18, 2016; Accepted: August 5, 2016; Published: August 31, 2016

\begin{abstract}
This study sought to examine the economic implication of EPAs on Kenya. In particular to analyze trade relations between Kenya and EU, the implications of EPAs on regional trade and other trade arrangements and welfare effects on Kenya. Using trade statistics analysis and partial equilibrium approach, the study found out that Kenya's exports to the EU market are dominated by a narrow range of primary commodity exports that include cut flowers, tea, coffee, vegetables and fish. The perceived preference margins that Kenya is to enjoy with the conclusion of EPAs are declining and will continue to decline in the future because EU is also negotiating FTA with other countries/regions and that multilateral trade liberalization under the WTO implies continued decline of tariffs and other trade barriers in the future. On trade arrangements, the study found out that the conclusion of the WTO Doha Round will increase competition in the EU market and reduce policy space and flexibility that Kenya has negotiated under the Doha Round of negotiations. Although the simulation results show loss of tariff revenue as a result of trade liberalization, these are compensated for through net welfare gains as a result of reduced consumer prices and also increased trade creation. On the policy front, the study recommends that for Kenya to benefit from EPAs there is need to urgently address supply side constraints such as inadequate infrastructure, low productive capacity of producers which limits exportable surplus among others. Kenya should also enhance export growth and diversification away from limited primary and natural resource based commodities. In addition Kenya should work on its competitiveness to retain and benefit from trade agreements such as the EPAs. This is because tariff and other trade barriers are decreasing over time in the international markets.
\end{abstract}

Keywords: Preference Margins, Trade Arrangements, Doha Round, Welfare Effects

\section{Introduction}

Prior to the signing of Economic Partnership Agreements (EPAs) in October 2014, trade relations between the European Union (EU) and Africa, Caribbean and Pacific (ACP) countries were guided by various agreements. These include: the Lome Conventions (1975-2000), the Cotonou Agreement (2001-2007) and the Framework for Economic Partnership Agreement (FEPA) (2007-2014).

Under the Lome Convention, the ACP countries enjoyed non-reciprocal ${ }^{1}$ market access on almost all exports (except for some agricultural products such as sugar and rice) to the

1 ACP countries did not have to provide equivalent trade benefits to the EU
EU. The Lome Conventions however were not compatible with Article XXIV of the General Agreement on Tariffs and Trade (GATT) which requires that all preferential trade agreements (PTAs) should be reciprocal but can be asymmetrical in favour of developing countries. The Lome conventions were also against the World Trade Organization (WTO) principle of the most-favoured-nation (MFN) treatment contained in Article I of the GATT $^{2}$ because it discriminated against other developing countries outside the

2 The Article I has a golden rule, "do unto others as you do to your best trading partner." This is MFN clause which states that countries cannot normally discriminate between their trading partners. Grant someone a special favour (such as a lower customs duty rate for one of their products) and you have to do the same for all other WTO members. 
ACP group and with similar economic circumstances.

To continue to discriminate in favour of ACP and derogate from her international trade commitments, the EU applied for waiver from WTO in 2001. The waiver was meant to allow the EU to provide non-reciprocal, duty free market access to ACP countries during the intervening period between 2002 and 2007. The WTO Ministerial meeting of 2001 granted the waiver to EU and ACP and as a result the Cotonou Agreement which came into force in April 2003. For the waiver to be granted, the EU agreed to compensate her trading partners that felt that their trading rights were being curtailed by the ACP-EU trading arrangement.

Under the Cotonou Partnership Agreement, the EU was to negotiate and conclude reciprocal new WTO-compatible trading arrangements with ACP, progressively removing barriers to trade between them and enhancing cooperation in all areas relevant to trade. These trade arrangements are referred to as the Economic Partnership Agreements (EPAs).

The EPAs negotiations were however not completed by the December $31^{\text {st }} 2007$ according to the waiver granted and therefore the EU proposed the initialing of interim framework EPAs, to provide a bridge until the conclusion of the negotiations. The interim EPAs contained a WTO compatible market access offer as well as a commitment to negotiate outstanding issues in the EPA.

On $28^{\text {th }}$ November 2007 in Kampala Uganda, EAC partner states and the EU initialed an interim Framework for Economic Partnership Agreement (FEPA) that comprised of: general provisions (scope, objectives and principles), trade in goods, fisheries, economic and development cooperation, provisions on areas for future negotiations, institutional and final provisions and annexes and protocols.

The interim framework agreement was to be replaced by a comprehensive EPA with effect from $1^{\text {st }}$ July 2009, by which time negotiations of all pending issues would have been concluded. However this deadline was not met because and by 2013 a number of areas (about 98\%) had been concluded. These areas included customs and trade facilitation, standards, and sanitary and phyto-sanitary measures and technical barriers to trade (TBT), fisheries, and economic and development co-operation text. Some of the contentious issues that delayed the conclusion of negotiations included market access issues, agriculture Text (domestic support and export subsidies) and economic and development cooperation, and new issues introduced by the EU- cooperation in the tax area and issues of human rights and governance.

In spite of the missed deadlines, the EPAs negotiations were finally completed and signed in Brussels Belgium in October $14^{\text {th }} 2014$. And with the signing of EPAs, this means that Kenyan/EAC exports to the EU will continue to access the market duty-free quota-free (DFQF) except for HS 93-arms and ammunition (on which MFN rates apply). The Comprehensive EPAs that was signed has inbuilt flexibilities including: asymmetric agreement in favour of the EAC in terms of the level of trade liberalization; excluded products (sensitive products); trade remedies provisions such as safeguard and countervailing measures; amendment clause when there is need to notify intentions to make amends to any section (including tariffs); a review clause (the agreement can be reviewed after 5 years) and an exit clause where a partner will require to issue a notice of one year to the other parties (Rotich, 2015).

In the agreement, for trade in goods, the EU will liberalize $100 \%$ of its market. On the other hand, the EAC has offered to liberalize $82.6 \%$ of its market within a transition period of 25 years in three phases as follows:

i. The first phase is planned to take 5 years and involves only products with a Common External Tariff (CET) of zero percent, i.e. products covered in this phase do not attract any import taxes under the EAC Customs Union CET (these are raw materials or capital goods). This constitutes $65.4 \%$ of EAC's imports from the EU. This means that in the first phase there is no change in EAC as EAC CET is already in place.

ii. The second phase will take 8 years within which the EAC Partner States will liberalize a further $14.6 \%$. Products in this category are intermediate inputs and attract $10 \%$ duty.

iii. The third phase will take 13 years within which the EAC Partner States will liberalize a further $2.6 \%$ of her imports from the EU. Included in this phase are finished products whose availability at lower cost is deemed to have a positive effect on consumer welfare, and not to have a potentially negative impact on EAC economies.

Under the Agreement, the $17.4 \%$ of products excluded from liberalization were identified based on contributions to rural development, employment, livelihood sustainability, promotion of food security, fostering infant industries, contribution to government revenues. In addition, products that were deemed to contribute or to have a potential to contribute to increased production and trade competitiveness were excluded from the list (see appendix 1).

There are several advantages that are likely to accrue to the country with the signing of EPAs. These include: increased predictability and credibility of the Kenyan economy, integration into the global supply chains, potential market access and increased welfare through access to cheaper imports from the EU among others. Despite these advantages, Kenya and other ACP countries are concerned with the possible negative effects of EPAs as identified by Fontagne et al., (2008). These include: increased competition of Kenya/EAC producers from EU producers, a likelihood of significant revenue loss due to tariff cuts, potential welfare losses or adjustment costs in the case where domestic production is undermined by cheap EU imports, or where more efficient producers from the rest of the world are displaced among others. These fears are compounded by the fact that in spite of the free access to the EU market for Kenyan products under the past agreements, the Kenyan exports to EU have been declining overtime. For Example the Kenyan exports to EU reduced from 29 percent of total Kenyan exports in 2009 to 25 percent in 2013 (KNBS 2014). In addition, Kenya has not been able to diversify her exports to EU and continue to rely on primary products including 
vegetables materials, coffee and tea (17\%) (See Table A1 in the appendix).

On the other hand, Kenya continues to imports high technology products from EU that has averaged around $20 \%$ of the total Kenyan imports in the last five years. Leading imports include motor vehicles $(6 \%)$, medicaments $(4 \%)$, paper and paperboard (4\%) among others. (See Table A2 in the appendix).

Based on the above, this paper therefore seeks to assess the implications of EPAs on Kenya's trade, revenue and welfare effect.

The rest of the paper is organized into four sections as follows: Section two provides literature review and section three outlines the methodology. Section four presents the key findings while section five gives conclusion and policy recommendations.

\section{Literature Review}

EPAs are trade arrangements which meant to create a Free Trade Area (FTA) between EU and ACP group of States. There is a domino effect which encourages countries to form regional economic blocs. According to Baldwin (1993), this arises from the fear of exclusion from the expected gains of trade arrangement; that is countries that are not members will have their profits and market share damaged. Countries have been motivated to form PTA due to frustrations arising from slow pace of trade negotiations under the WTO. It has been argued that the PTAs can complement multilateral trade liberalization. Most of the countries especially in Africa therefore enter into regional economic communities (RECs) to overcome limitations associated with small market and increase their voice and negotiations in the international fora.

PTA can be referred to as union of two or more countries among which lower or zero tariffs are imposed on each other relative to what is imposed to non-members (Panagariya, 2000). The countries in question may not necessarily share a boundary as is the case between trade relations between the ACP and EU countries under the EPAs (WTO, 2011).

The theoretical underpinning of PTA traces its origin from Viner (1950) in his early work on the formation of a customs union. The static welfare analysis focused on the changes in production structure following the formation of an FTA in order to determine trade creation or trade diversion. Trade creation is welfare enhancing while trade diversion reduces national welfare. The overall effect on welfare depends on the relative sizes of the two. When trade creation predominates trade diversion, then there is an overall welfare gain and vice versa.

Lipsey (1957) makes an argument that negative effects of trade diversion on welfare emanates from implicit exclusion of consumption effect. According to this argument, gains from reduced prices of imports could possibly offset losses arising from shifting production from a low cost producer outside the FTA, to a higher cost producer within the FTA. Thus, a member country can gain welfare from an FTA even in the presence of trade diversion. Bhagwati (1971) further argues that absence of substitution in consumption may not necessarily be welfare decreasing. According to him, welfare decreasing effects of trade diversion happens with restriction on imports rather than consumption pattern.

Welfare effects resulting from FTA formation are not solely determined by trade creation or trade diversion. The degree of cost saving from trade created and added costs as a result of trade diversion also matter. In addition, tariff revenue loss as a result of reduction or elimination of tariffs might outweigh net gains from trade creation and consumption effect. This is more so where tariff elimination does not translate into lower domestic prices. The higher the tariff preference, the larger would be the welfare loss from an FTA (Adamu, 2013). There are instances when the formation of an FTA may make member states to increase protectionist tendencies against non-members. As a consequence, endogenous protection converts any trade creation within the FTA into trade diversion (Bhagwati and Panagariya, 1996).

The empirical literature on the implications of EPAs is quite diverse with different results. For example, a study by Karingi et al. (2005), found that revenue loss was low for countries in Southern African Customs Union (SACU) but significant for the other countries. Mkenda and Hangi (2009) found that revenue loss from tariff reductions was very significant for Tanzania while Zouhon-Bi and Nielson (2007) revealed that the impact of fiscal revenue for Economic Community of West African States (ECOWAS) countries would be significant. According to Milner, et al. (2005), the welfare effect, whether positive or negative for the EAC countries was small. Milner, et al. (2002) observed that EPAs would enhance SSA exports and competitiveness and that EPAs would be more efficient than multilateralism.

Morrissey and Zgovu (2009) found that more than half of the ACP countries were likely to realize welfare gains. However, the overall effect on gross domestic product (GDP) growth, whether positive or negative was very small while potential losses of tariff revenue were non-negligible. Berisha-Krasniqi, et al. (2008) observed that for countries in Southern African Development Community (SADC), Eastern and Southern Africa (ESA), the Caribbean and Pacific, EPAs was trade creating, but trade diverting for Nigeria, Senegal and Western, Eastern, and Central Africa (WECA). Keck and Piermartini (2005) found that EPAs were welfare enhancing on SADC countries and will lead to an increase in real GDP. Perez and Karingi (2006) points out EPAs would create asymmetrical gains between African and EU producers. KIPPRA (2005) on the other hand found a net welfare gains for the Kenyan economy ranging between +0.7 percent and -0.1 percent of GDP. However after including sensitive products, EPAs were welfare enhancing but trade creation was in favour of the EU with a possibility of 14 percent substitution from EAC countries to the EU.

\section{Methodology}

The study employs a partial equilibrium model (PEM) flowing Panagariya (1998) and Milner et al (2005) to achieve her objectives.

The framework distinguishes between those sectors where 
group and the rest of the world (ROW) is the dominant supplier and those where EU is the dominant supplier prior to EPA formation. The model distinguishes three blocks of countries i.e. the European Union (EU), the EAC (ROW). In this regard, three components of the trade effects are simulated i.e. consumption effect/revenue effects; trade diversion effects and trade creation effects.

Case 1: Consumption Effects only

In the sectors where the EU is globally efficient and therefore the dominant supplier to the EAC market before the formation of the EPA, it can be assumed that only consumption effects would follow from the EPA. Thus, for the sectors where the EU is the dominant supplier, consumption effect alone $\left(\Delta M^{C}\right)$ can be estimated relative to the existing EU import levels as follows:

$$
\Delta M^{C}=\left[\frac{t}{1+t}\right] \cdot e_{M}^{D} \cdot M_{0}^{E U} \cdot U V_{0}^{E U}
$$

Where $\mathrm{t}$ is the current tariff against imports from the EU, $e_{M}^{D}$ is the price elasticity of demand of imports, $M_{0}^{E U}$ is the current volume of imports from the EU and $U V_{0}^{E U}$ is the current average unit value of imports from the EU. The revenue $\left(\Delta R^{C}\right)$ and welfare $\left(\Delta W^{C}\right)$ effects associated with this are correspondingly:

$$
\begin{gathered}
\Delta R^{C}=-t . U V_{0}^{E U} M_{0}^{E U} \\
\Delta W^{C}=0.5 t . \Delta M^{C}
\end{gathered}
$$

Case 2: Trade Diversion with Consumption Effects

For those sectors in the EAC where the ROW is the dominant supplier, further assumptions regarding the competitiveness of EU supply to the EAC is required. If PEU $<$ PtROW then, given constant cost technology over the relevant range, the EPA will divert all the imports for ROW to the EU. Thus, the upper limit of the value of trade diversion $\left(\Delta M^{T D}\right)$ is:

$$
\Delta M^{T D}=M_{0}^{R O W} \cdot U V_{0}^{R O W}
$$

Where $M_{0}^{R O W}$, is the current quantity of imports from ROW and $U V_{0}^{R O W}$ is the current average unit of imports from ROW. The tariff revenue effect $\left(\Delta R^{T D}\right)$ due to this trade diversion is given by:

$$
\Delta R^{T D}=-t U V_{0}^{R O W} M_{0}^{R O W}
$$

For these sectors, there will also be consumption effects $\left(\Delta M_{T D}^{C}\right)$

Given that one may not have information about where the price of EU imports may lie between $\mathrm{P}_{\text {ROW }}$ and $\mathrm{P}_{\text {ROW }}^{t}$, one can take an average of the two and assume that is where $\mathrm{P}_{\mathrm{EU}}$ lies as follows:

$$
\Delta M_{T D}^{C}=0.5\left[\frac{t}{1+t}\right] \cdot e_{M}^{D} \cdot M_{0}^{R O W} \cdot U V^{E U}
$$

Given the assumption about PEU, the overall welfare $\left(W^{T D}\right)$ can be approximated-impact of trade diversion with consumption effects as follows:

$$
W^{T D}=0.25 t \Delta M_{T D}^{C}-0.5 t U V_{0}^{R O W} M_{0}^{R O W}
$$

Case 3: Trade Creation with Consumption Effects

Assuming that the EU is more efficient supplier that the ROW, if the duty free supply price from the EAC partner lies over the relevant range between PtROW and PEU, then all of the current imports from the region to the home country will be replaced by more efficient production from the EU. Therefore, the maximum value of trade created $\left(\Delta M^{T C}\right)$ for the EU by this deflection from EAC region sources can be estimated by:

$$
\Delta M^{T C}=M_{0}^{E A C} \cdot U V^{E A C}
$$

Where $M_{0}^{E A C}$, refers to the current quantity of imports from EAC partner and $U V^{E A C}$ is the current average unit value of imports from EAC partner.

In order to estimate consumption effects in these sectors ( $M_{T C}^{C}$ ), assume that the price from the EAC partner is as high as the tariff-inclusive price from the EU. In this case, the pre-EPA tariff rate against the EU imports provides an (upper) estimate of the extent to which the import price can fall as a result of the EPA. Thus:

$$
M_{T C}^{C}=0.5\left[\frac{t}{1+t}\right] \cdot e_{M}^{D} \cdot M_{0}^{E A C} \cdot U V^{E U}
$$

The combine welfare ( $\Delta W^{T C}$ ) effects of trade creation with consumption effects can be identified by:

$$
\left.\Delta W^{T C}=0.5 t \cdot M_{T C}^{C}+\left(U V^{A C P} M_{0}^{A C P}\right) t\right)
$$

The simulations are carried out in three scenarios:

a). The first scenario basically being liberalization during the first year into the EPAs. During this phase, the tariffs for products under Annex IIB of the consolidated EPA text are reduced by $20 \%$ i.e. from $10 \%$ to $8 \%$, while those under Annex IIC are reduced by 5\% i.e. from $25 \%$ to $23.8 \%$.

b). In the second scenario which will take place after 8 years into the EPAs, tariffs for products under Annex IIB are reduced by $100 \%$ to zero, while those under Annex IIC are reduced by $20 \%$.

c). The final scenario is where the products under annex IIC of the schedule are reduced to zero and upon which liberalization will cover $82.6 \%$ of the tariff lines.

The paper used Kenyan data for the year 2013. The data was disaggregated at HS 8 digit levels and at source levels i.e. the EAC, EU and Rest of the World. In addition, the study used data on import duties as well as domestic taxes including VAT 
and excise duties to carry out various simulations. The trade data utilized in this study has been obtained from Kenya Revenue Authority (KRA), International Trade Centre (ITC), and Export Promotion Council (EPC).

\section{Findings}

\subsection{Implication of EU Trade Agreements with Other Countries/Regions to Kenya}

Since 1963, the EU has signed and is negotiating bilateral trade agreements with many countries and regions of the world whose effect is the reduction of tariff and other barriers to trade (for example quotas and less restrictive rules of origin) on selected goods. The EU has 12 trade negotiations currently under negotiation, 10 trade negotiation agreements that are complete and yet to enter into force, and thus the EU has trade agreements with some 50 partners. As the EU continues to offer trade preferences to these countries/regions, the preferential margin available for Kenyan products will continue to shrink. Some of these countries will pose competition for some of Kenyan products in the EU. For instance, the EU has already concluded FTA with Colombia which is a major exporter of cut flowers which is the leading export commodity by Kenya to the EU.

\subsection{Implication of EPAs on Other Trade Arrangements}

\subsubsection{Tripartite Free Trade Area (TFTA) Negotiations}

The three regional economic communities (RECs), EAC, COMESA and SADC launched the negotiation for the establishment of TFTA in June 2011 in South Africa. The TFTA was finally signed in June 2015 in Egypt. The TFTA negotiations comprises of the 26 countries, 22 of which are already participating in their respective FTAs, therefore forming a critical mass necessary to establish Tripartite FTA.

The launch of the TFTA was out of the recognition of the growing importance of intra-African regional trade and therefore the need to, among others, to remove trade barriers and harmonize trade policies within the three regional blocks. However the three regional blocs have signed with the EU different interim agreements with different-content, schedules of implementation and exclusion list (sensitive list of products). This in away creates three trade regimes within the TFTA and hence fragmenting rather than integrating the RECs with the consequences of hampering deeper regional integration. Over and above this scenario, South Africa already has an FTA-TDCA with the EU which puts another layer of complexity in harmonizing the three RECs. The three RECs are negotiating EPAs with the EU separately and in different configurations. For example we have the SADC-EPA, the EAC-EPA and the ESA-EPA. Already the EAC, SADC and some individual countries within the framework of ESA have initialed different interim agreements with the EU under EPAs on trade in goods (see Table A3 in the appendix).

The negotiations for EPAs agreement with the EU may have a negative impact on Africa's regional integration process. This is because regional markets will be opened up to the EU before they are consolidated internally. It is important for the African regional groupings to be sufficiently integrated among themselves before they sign the final EPA agreements FTA, otherwise the conclusion of an EPA could potentially undermine harmonization in terms of the common external tariff (CET), customs clearance procedures and documentations among others in the three RECs.

In the TFTA regions, only the EAC has a harmonized list of products to be excluded from liberalization. Among the three trade blocs forming the TFTA, EAC is the most advanced and already has a customs unions and is implementing the common market protocol, this is not the case with COMESA and SADC. Within COMESA, there are countries (for example Djibouti, Ethiopia, Eritrea and Sudan) that might not have incentives to join the EPAs because they can gain DFQF market access under everything but arms (EBAs) (EU, 2014). There is thus a likelihood of increasing heterogeneity in the trading blocs and in effect complicate their harmonization. There is however a view that since trade negotiations are undertaken by one team, that is, the team that negotiates for Kenya in the EAC, COMESA, and EPAs is the same team that is negotiating the TFTA, it can therefore be anticipated that some of the complications that might be encountered in the EPAs and related to the regional trade arrangements will be taken into account.

\subsubsection{WTO Trade Negotiations}

One of the key principles of the WTO multilateral trade system is that reductions in trade barriers should be applied, on a MFN nation basis, to all WTO members. This means that no WTO member should be discriminated against by another member's trade regime. However, RTAs are an important exception to this rule. Under RTAs, reductions in trade barriers apply only to the parties to the agreement.

During the fourth WTO Ministerial Conference in November 2001 in Doha, Qatar, a new round of trade negotiations was launched (The Doha Round). The Doha negotiations were aimed at achieving major reforms of the international trading system through lowering trade barriers and revising trade rules. The Doha Round of negotiations was expected to be concluded by $1^{\text {st }}$ January 2005. However this deadline and other subsequent ones have been missed due to divergences among the members on some of the issues under negotiations and also differences between developed countries and emerging economies especially China, India and Brazil. Because of the slow progress in the negotiations, some issues were selected from the broader Doha Round and agreed upon during the $9^{\text {th }}$ WTO Ministerial Conference that was held in December 2013 in Bali, Indonesia. These issues are: trade facilitation; agriculture (food security, export competition and tariff rate quota administration); development and least developed countries issues (Monitoring Mechanism for Special and Differential Treatment, Preferential Rules of Origin for LDCs, a waiver on preferential Treatment to services and services suppliers of LDCs and the DFQF Market Access for LDCs and Cotton).

In the $10^{\text {th }}$ WTO Ministerial conference held in Nairobi, Kenya in December 2015, several decisions were agreed upon 
including a commitment to abolish export subsidies for farm exports, public stockholding for food security purposes, a special safeguard mechanism for developing countries, and measures related to cotton including market access, domestic support and export compensation. Other achievements included enhanced preferential rules of origin for LDCs and preferential treatment for LDC services providers. However despite these achievements there are many contentious issues which need to be ironed out and hence it is difficult to anticipate when the Doha Round of negotiations will be concluded.

The EPAs, as a free trade agreement is supposed to be compatible with the WTO rules. Consequently, the conclusion of the Doha Round will have an impact on EPAs in a number of ways. Although the Doha Round of negotiations has not been concluded, the proposals and the convergences reached on some of the issues under discussions will have ramifications on EPAs.

On WTO RTA, there is a mandate under the Doha Round aimed at clarifying and improving disciplines and procedures under the existing WTO provisions applying to regional trade agreements. The negotiations on RTAs are also supposed to take into account the developmental aspects of RTAs. The ACP countries Kenya included, submitted a proposal on several aspects of special and differential treatment (SDT) to be considered in the context of the RTAs negotiations. For instance, the ACP countries proposed that the threshold for substantially all trade on the basis of tariff liberalization should be $60 \%$ to $65 \%$ for developing countries in their arrangements with developed country members. Under EPAs, the EAC has however agreed to liberalize $82.6 \%$ which is higher than what has been proposed in the WTO Doha negotiations. Before the EPAs negotiations, the value of EU exports entering the EAC that had been zero rated under CET was $65.4 \%$ affecting 1920 tariff lines. This level of market access would have been therefore sufficient for the EAC under EPA framework in line with the ACP proposal at the WTO.

The current proposed modalities for liberalization of agriculture sector under the Doha Round will also have an impact on EPAs once the Round is concluded. The EPAs offers duty free market access for most of Kenyan export products to the E.U market among them cut flowers, fresh fruits and vegetables. However under the Doha Round negotiations on agriculture, the tariff lines on cut flowers, and fresh fruits and vegetables appear on the list of tropical products that should be zero-rated. The EU will therefore also be required to reduce their MFN tariffs in other agricultural products which will definitely erode preferences that Kenya would have secured under the EAC-EU EPA framework. This will have a major impact on the Kenyan economy since exports of cut flowers, fruits and vegetables comprise a major share of Kenyan total exports. For example in 2013, Kenya's exports of these products to the EU market was to the tune of US\$ 400 million annually and offers employment to more than 3 million people.

Under the Doha Non-agricultural market access (NAMA) negotiations, sectoral approach is being pursued to achieve the overall objective of reducing or eliminating tariffs as appropriate. The tariffs in the EU for some of the sectors that have been proposed for sectoral negotiations such as fish and fish products, and textiles and apparels will be drastically reduced or eliminated. The EU maintains relatively high MFN tariffs in these two sectors and therefore the value of preferences given to Kenya under EPA framework will considerably be reduced or eliminated under the Doha Round negotiations. In addition, the conclusion of the Doha Round will also increase competition in the EU market and therefore Kenyan exporters to the EU market will have to be competitive in order to maintain or increase their exports to this market.

Besides preference erosion, policy space and flexibility that Kenya has negotiated under the Doha Round will be eroded under the EPA framework. For instance in NAMA negotiations, Kenya will be exempted from applying the proposed tariff reduction formula but will be required to increase tariff binding covered from 1.6 percent to 75 percent and achieve an average level that does not exceed 30 percent over a period of 10 years. This will not have an impact on applied tariffs thereby giving Kenya adequate policy flexibility to use tariffs as a tool for industrialization. This flexibility has been eroded under EPA framework since Kenya will be expected to reduce its applied tariff on EU imports which is likely to affect domestic industries through increased competition.

\subsection{Economic Implication of EPAS to Kenyan}

The simulations are carried out in three scenarios (see methodology)

For products under annex IIB and IIC, see the EAC-EU EPA consolidated text ${ }^{3}$.

The results are analyzed based on the product category as provided in Table 1.

Table 1. Product categorization by Chapters.

\begin{tabular}{|c|c|c|}
\hline & Chapters & Product descriptions \\
\hline 1 & $1-5$ & Live animals, animal products \\
\hline 2 & $6-14$ & Vegetable products \\
\hline 3 & 15 & $\begin{array}{l}\text { Animal or vegetable fats and oils and their cleaverage } \\
\text { products }\end{array}$ \\
\hline 4 & $16-24$ & $\begin{array}{l}\text { Prepared foodstuffs, beverages, spirits and vinegar, } \\
\text { tobacco }\end{array}$ \\
\hline 5 & $25-27$ & Mineral products \\
\hline 6 & $28-38$ & Products of chemical or allied industries \\
\hline 7 & $39-40$ & Plastics and articles thereof, rubber and articles thereof \\
\hline 8 & $41-43$ & $\begin{array}{l}\text { Raw hides and skins, leather, furskins and articles } \\
\text { thereof }\end{array}$ \\
\hline 9 & 44-46 & $\begin{array}{l}\text { Wood and articles of wood, wood charcoal, cork and } \\
\text { articles of charcoal }\end{array}$ \\
\hline 10 & $47-49$ & $\begin{array}{l}\text { Pulp of wood or other fibrous cellulosic material, paper } \\
\text { or paper boards }\end{array}$ \\
\hline 11 & $50-63$ & Textiles and textile articles \\
\hline 12 & $64-67$ & Footwear, headgear, umbrellas, walking sticks \\
\hline 13 & $68-70$ & $\begin{array}{l}\text { Articles of stone, plaster, cement, asbestos, mica or } \\
\text { similar materials }\end{array}$ \\
\hline 14 & 71 & $\begin{array}{l}\text { Natural or cultured pearls, precious or semiporous } \\
\text { stones }\end{array}$ \\
\hline 15 & $72-97$ & $\begin{array}{l}\text { Base metals, machinery, vehicles \& transport } \\
\text { equipment, arms, optical etc }\end{array}$ \\
\hline
\end{tabular}

3 trade.ec.europa.eu/doclib/docs/2010/.../tradoc_145792.pdf 


\subsubsection{Tariff Revenue Effects}

This is estimated for those sectors where the EU is the globally efficient and dominant supplier to the EAC region. The results indicate that there will be gradual reductions in tariff revenues following gradual reduction of tariffs as per the schedule for liberalization. Thus, total tariff revenues will reduce from ksh 9.8 billion to ksh 9.4 billion during the first phase (year) of liberalization and to ksh 7.9 billion during the second phase of liberalization. The revenue losses due to the first phase of liberalization would be about ksh 362 million from the baseline data.

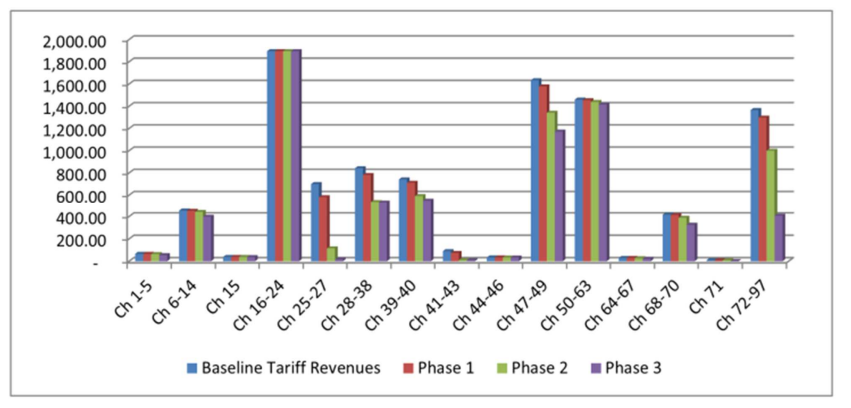

Source: Simulation Results

Figure 1. Tariff Revenues Changes (Value-Ksh Millions).

In addition, the biggest revenue losses would be incurred from the products under chapter 25-27 (33\%), chapters 72-97 (19\%), 28-38 (17\%) and chapters $47-49(15 \%)$ It is also notable that products under chapters 15 and 16-24 will have minimal or negligible revenue losses due to their excludability from liberalization.

\subsubsection{Trade Creation Effects}

Assuming the EU is a more efficient supplier than the ROW, then all current imports from the ROW would be replaced by more efficient production from the EU. As a result of tariff reductions, increased imports from the EU would be realized from the initial value of about ksh 8.3 billion increases to ksh 10.7 billion and ksh 13.4 billion during the first phase and second phase of liberalization respectively.

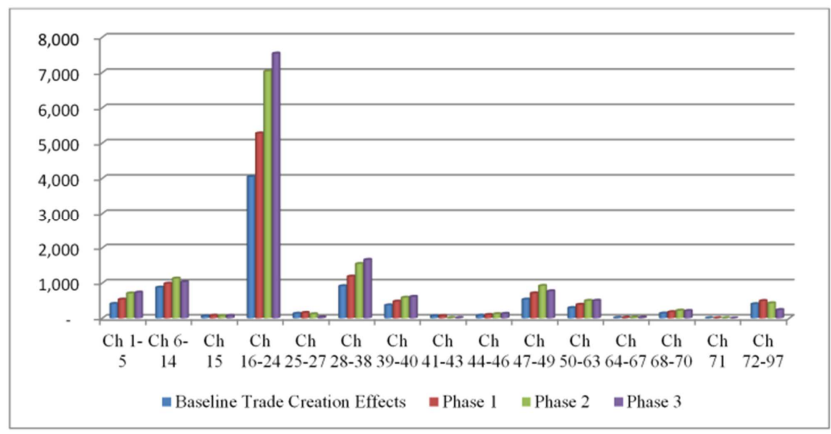

Source: Simulation Results

Figure 2. Trade Creation Effects.

The bulk of the trade creation would be derived from the products under chapters 16-24 (53\%), 28-38 (12\%) and 6-14
(5\%) during the phase one of liberalization.

The largest increase in trade creation occurs for prepared foodstuffs, beverages and mineral products under chapters 16-24 i.e. prepared food stuffs, beverages, spirits and vinegar, tobacco and 28-38 (Products of chemical or allied industries), respectively under phase one and two of liberalization. It is also notable that there are reductions in trade under some category of products i.e. under chapter 71 of the product classifications during the $1^{\text {st }}$ phase of liberalization. On the other hand, the second phase of liberalization leads to reduction in trade creation with the EU for products under chapters 25-27 i.e. mineral products and 41-43 or raw hides and skins, leather, fur skins and articles thereof, while the third phase of liberalization sees a significant reduction in trade for products under chapters 72-97 and chapter 71 .

\subsubsection{Trade Diversion}

These are effects when there is a shift of imports from the more efficient ROW producers to the EU region as a result of tariff phase-down in favour of EU producers. Since the tariff on products remains unchanged from the baseline line levels, the estimates given are indicative of the largest effects possible given the baseline figures. The biggest effects occur in chapters 6-14 (35\%), 72-97 (14\%) and $16-24(13 \%)$.

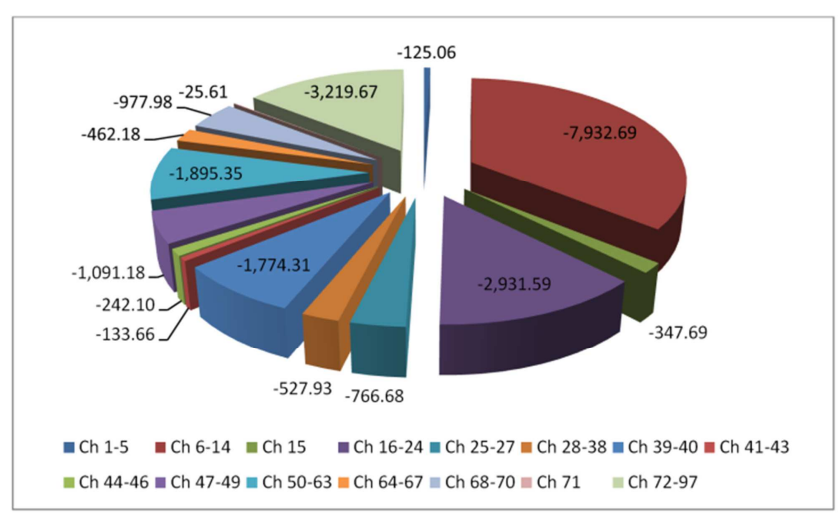

Source: Simulation Results

Figure 3. Trade diversion effects.

Considering that the value of Kenya's imports from the EU was Ksh. 100.6 billion (Figure 3), the value of trade diverted from more efficient suppliers to the Kenyan market to the EU is about $22.3 \%$.

\subsubsection{Welfare Effects}

This constitutes consumption effects arising from trade creation and trade diversion effects. The biggest net welfare effects take place during the phase 2 of liberalization whereby the net effect of about Ksh 560 million (Figure 4) are derived. During the time, the largest welfare gains are derived from products under chapters 16-24 i.e. prepared foodstuffs, beverages, spirits and vinegar, tobacco) and 50-63 (textiles and textile articles), showing the importance of these products these products to the Kenyan economy. 


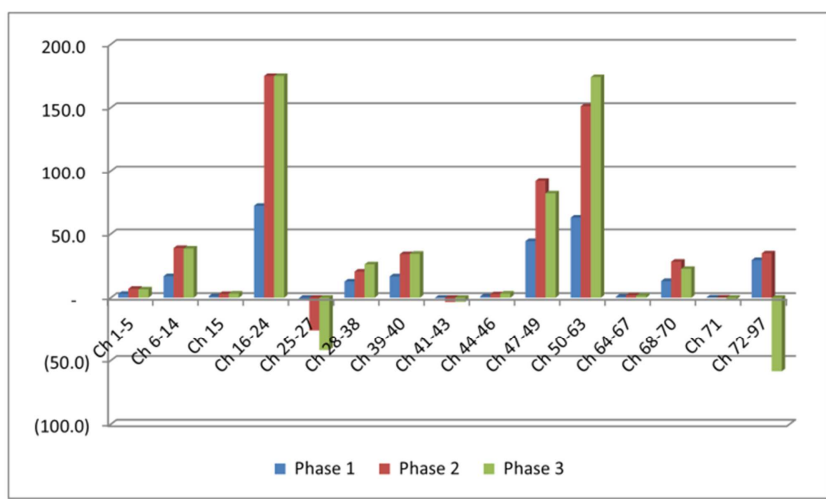

Source: Simulation Results

Figure 4. Change in Welfare Effects during Liberalization (Ksh Millions).

\section{Conclusions and Recommendations}

Kenya's exports to the EU market are dominated by a narrow range of primary commodity exports that include cut flowers, tea, coffee, vegetables and fish. Given that most of these exports are mainly agricultural commodities, increased exports in this area will depend on how Kenyan exporters are able to meet technical standards. With the conclusion of EPAs, there is a likelihood of SPS escalation including private standards in the EU market.

The perceived preference margins that Kenya is to enjoy with the conclusion of EPAs are declining and will continue to decline in the future because of two reasons. First, EU has already concluded trade negotiations or is under negotiation with other countries/regions. A case in point is the already concluded FTA agreement between the EU and Colombia which is also a major producer of cut flowers as Kenya. Second, the multilateral trade liberalization under the WTO implies continued decline of tariffs and other trade barriers in the future. Thus, with or without an agreement at multilateral level in the immediate future, preference erosion is unavoidable over time. In addition, the conclusion of the Doha Round will also increase competition in the EU market and therefore Kenyan exporters to the EU market will have to be competitive in order to maintain or increase their exports to this market. In this regard, the EPAs will only provide a temporary advantage to Kenya in terms of market access for some products.

The conclusion of EPA negotiations will mainly serve mainly to preserve current market access by Kenya in the EU and avoidance of market disruption. As such, no substantial market access improvement can be anticipated by Kenya because already Kenyan products have been entering the EU market DFQF under the interim EPAs. This is unless market access constrains are eliminated and export capacity is developed in the short, medium and long-term. The degree to which Kenya benefits will be dependent upon the degree of Kenya's supply-side flexibility, flexibility of the rules of origin (RoO) already negotiated, the extent of NTBs especially SPS norms, and the scope and levels of economic and development cooperation.

Although the simulation results show loss of tariff revenue as a result of trade liberalization, these are compensated for through net welfare gains as a result of reduced consumer prices and also increased trade creation. Besides, the importance of tariff revenues as a share of government revenue has been declining over time following diversification of sources of government revenue. In addition, some of the imported products also attract domestic taxes such as VAT and excise duties. The results indicate overall welfare gains with the conclusion of EPAs.

On the policy front, the study recommends that for Kenya to benefit from EPAs there is need to urgently address supply side constraints such as inadequate infrastructure, low productive capacity of producers which limits exportable surplus among. The country and the region need to tighten the institutional and regulatory framework of regional standards for commodities. Thus, the conclusion of EPAs should be accompanied by a comprehensively negotiated financial facility under the development component to address issues of competitiveness. This is also due to the fact that there is a great divergence between the EU and the ACP countries in terms of the level of development and thus trade relation between them should be asymmetric. The EU trade preferences to ACP countries and therefore to Kenya should enhance export growth and diversification away from limited primary and natural resource based commodities. Kenya should urgently embark on an industrialization strategy to diversify exports especially high technology exports. The country can diversify by venturing into the production of textiles and articles of apparel for EU which has been identified as a high potential growth area in terms of exports and utilizes the labour intensive production strategy that is advantageous to Kenya.

Overall, it can be concluded that Kenya has to work on its competitiveness to retain and benefit from EPAs. This is because tariff and other trade barriers are decreasing over time in the international markets.

\section{Appendix}

\section{List of EAC Exclusion List}

Live animals; meat and edible meat offal; fish and crustaceans, molluscs and other aquatic invertebrates; dairy produce; birds' eggs; natural honey; edible products of animal origin; live trees and other plants; bulbs, roots and the like; cut flowers and ornamental foliage; edible vegetables and certain roots and tubers; edible fruit and nuts; peel of citrus fruits or melons; coffee, tea, maté and spices; cereals; products of the milling industry; malt; starches; vegetable plaiting materials; vegetable products nes; animal or vegetable fats and oils and their cleavage products; prepared edible fats; animal or vegetable waxes; preparations of meat, of fish or of crustaceans, molluscs or other aquatic invertebrates; sugars and sugar confectionery; cocoa and cocoa preparations; preparations of cereals, flour, starch or milk; pastry cooks' products; preparations of vegetables, fruit, nuts or other parts of plants; miscellaneous edible preparations; beverages, spirits and vinegar; residues and waste from the food industries; 
prepared animal fodder; tobacco and manufactured tobacco substitutes; plastics and articles thereof; wood and articles of wood; cotton; man-made filaments; man-made staple fibres; footwear, gaiters and the like; parts of such articles; iron and steel; and articles of iron or steel.

Table A1. Kenyan Export Commodities to the EU (2013).

\begin{tabular}{|c|c|c|c|c|c|}
\hline & $\begin{array}{l}\text { Article } \\
\text { (SITC) }\end{array}$ & Product Description & Value (Kshs) & $\begin{array}{l}\text { Share of } \\
\text { Total }(\%)\end{array}$ & $\begin{array}{l}\text { Cumulative } \\
\text { Share (\%) }\end{array}$ \\
\hline 1 & 292 & Crude vegetable materials, n.e.s. & $34,145,882,487$ & 31.41 & 31.41 \\
\hline 2 & 054 & $\begin{array}{l}\text { Vegetables, fresh, chilled, frozen or simply preserved (including dried leguminous } \\
\text { vegetables); roots, tubers and other edible vegetable products, n.e.s., fresh or dried }\end{array}$ & $18,382,113,500$ & 16.91 & 48.32 \\
\hline 3 & 074 & Tea and mate & $16,792,634,907$ & 15.45 & 63.76 \\
\hline 4 & 071 & Coffee and coffee substitutes & $14,397,044,882$ & 13.24 & 77.00 \\
\hline 5 & 292 & Crude vegetable materials, n.e.s. & $3,679,298,259$ & 3.38 & 80.39 \\
\hline 7 & 278 & Other crude minerals & $2,982,063,595$ & 2.74 & 86.29 \\
\hline 8 & 056 & Vegetables, roots and tubers, prepared or preserved, n.e.s. & $2,389,736,947$ & 2.20 & 88.49 \\
\hline 9 & 057 & Fruit and nuts (not including oil nuts), fresh or dried & $2,336,818,193$ & 2.15 & 90.64 \\
\hline 10 & 034 & Fish, fresh (live or dead), chilled or frozen & $1,379,185,252$ & 1.27 & 91.91 \\
\hline 11 & 611 & Leather & $1,297,645,079$ & 1.19 & 93.10 \\
\hline 12 & 037 & $\begin{array}{l}\text { Fish, crustaceans, molluscs and other aquatic invertebrates, prepared or preserved, n.e.s } \\
\text { Fruit juices (including grape must) and vegetable juices, unfermented and not }\end{array}$ & $1,268,767,833$ & 1.17 & 94.27 \\
\hline 13 & 059 & $\begin{array}{l}\text { containing added spirit, whether or not containing added sugar or other sweetening } \\
\text { matter }\end{array}$ & $1,192,981,764$ & 1.10 & 95.36 \\
\hline 14 & 121 & Tobacco, unmanufactured; tobacco refuse & $844,461,993$ & 0.78 & 96.14 \\
\hline 15 & 894 & Baby carriages, toys, games and sporting goods & $582,828,948$ & 0.54 & 96.68 \\
\hline 16 & 075 & Spices & $491,663,626$ & 0.45 & 97.13 \\
\hline 17 & 098 & Edible products and preparations, n.e.s. & $255,669,567$ & 0.24 & 97.36 \\
\hline 18 & 036 & $\begin{array}{l}\text { Crustaceans, molluscs and aquatic invertebrates, whether in shell or not, fresh (live or } \\
\text { dead), chilled, frozen, dried, salted or in brine; crustaceans, in shell, cooked by steaming } \\
\text { or bo }\end{array}$ & $224,592,695$ & 0.21 & 97.57 \\
\hline 19 & 288 & Non-ferrous base metal waste and scrap, n.e.s. & $220,953,595$ & 0.20 & 97.77 \\
\hline 20 & 265 & $\begin{array}{l}\text { Vegetable textile fibres (other than cotton and jute, raw or processed but not spun; waste } \\
\text { of these fibres }\end{array}$ & $162,094,047$ & 0.15 & 97.92 \\
\hline \multirow[t]{2}{*}{21} & & All Others & $2,257,784,198$ & 2.08 & 100.00 \\
\hline & & Total & $108,718,787,413$ & & \\
\hline
\end{tabular}

Source: KRA and Authors' Computation

Table A2. Kenyan Import Commodities from the EU (2013).

\begin{tabular}{|c|c|c|c|c|c|}
\hline & $\begin{array}{l}\text { Article } \\
\text { (SITC) } \\
\end{array}$ & Product Description & Value (Kshs) & $\begin{array}{l}\text { Share of } \\
\text { Total }(\%)\end{array}$ & $\begin{array}{l}\text { Cumulative } \\
\text { Share (\%) }\end{array}$ \\
\hline 1 & 783 & Road motor vehicles, n.e.s. & $12,026,583,475$ & 5.89 & 5.89 \\
\hline 2 & 542 & Medicaments (including veterinary medicaments) & $7,925,664,579$ & 3.88 & 9.77 \\
\hline 3 & 641 & Paper and paperboard & $7,548,411,951$ & 3.70 & 13.47 \\
\hline 4 & 764 & $\begin{array}{l}\text { Telecommunications equipment, n.e.s., and parts, n.e.s., and accessories of apparatus } \\
\text { falling within division } 76\end{array}$ & $6,729,520,218$ & 3.30 & 16.77 \\
\hline 5 & 792 & $\begin{array}{l}\text { Aircraft and associated equipment; spacecraft (including satellites) and spacecraft } \\
\text { launch; and parts thereof }\end{array}$ & $6,364,111,383$ & 3.12 & 19.89 \\
\hline 6 & 781 & $\begin{array}{l}\text { Motor cars and other motor vehicles principally designed for the transport of persons } \\
\text { (other than public-transport type vehicles) including station wagons and racing cars }\end{array}$ & $6,012,542,912$ & 2.95 & 22.83 \\
\hline 7 & 713 & Internal combustion piston engines, and parts thereof, n.e.s. & $5,346,288,497$ & 2.62 & 25.45 \\
\hline 8 & 098 & Edible products and preparations, n.e.s. & $5,175,373,719$ & 2.54 & 27.99 \\
\hline 9 & 716 & Rotating electric plant and parts thereof, n.e.s. & 5090391658 & 2.49 & 30.48 \\
\hline 10 & 334 & $\begin{array}{l}\text { Petroleum oils and oils obtained from bituminous minerals (other than crude); } \\
\text { preparations, n.e.s. containing by weight } 70 \% \text { or more of petroleum oils or of oils } \\
\text { obtained from bituminous } \mathrm{m}\end{array}$ & 4831322773 & 2.37 & 32.85 \\
\hline 11 & 562 & Fertilizers (other than those of group 272) & $4,820,127,895$ & 2.36 & 35.21 \\
\hline 12 & 728 & $\begin{array}{l}\text { Other machinery and equipment specialized for particular industries, and parts thereof, } \\
\text { n.e.s. }\end{array}$ & $4,164,305,601$ & 2.04 & 37.25 \\
\hline 13 & 745 & Other non-electrical machinery, tools and mechanical apparatus, and parts thereof, n.e.s. & $3,829,414,056$ & 1.88 & 39.12 \\
\hline 14 & 269 & Worn clothing and other worn textile articles; rags & $3,739,617,203$ & 1.83 & 40.96 \\
\hline 15 & 541 & Medicinal and pharmaceutical products, other than medicaments of group 542 & $3,736,245,076$ & 1.83 & 42.79 \\
\hline 16 & 591 & $\begin{array}{l}\text { Insecticides, rodenticides, fungicides, herbicides, anti-sprouting products and } \\
\text { plant-growth regulators, disinfectants and similar products, put up in forms or packings } \\
\text { for retail sale or }\end{array}$ & $3,540,990,674$ & 1.73 & 44.52 \\
\hline 17 & 752 & Automatic data proccessing machines and units thereof; magnetic or optical readers, & $3,207,544,833$ & 1.57 & 46.09 \\
\hline
\end{tabular}




\begin{tabular}{|c|c|c|c|c|c|}
\hline & $\begin{array}{l}\text { Article } \\
\text { (SITC) }\end{array}$ & Product Description & Value (Kshs) & $\begin{array}{l}\text { Share of } \\
\text { Total }(\%)\end{array}$ & $\begin{array}{l}\text { Cumulative } \\
\text { Share }(\%)\end{array}$ \\
\hline & & $\begin{array}{l}\text { machines for transcribing data onto data media in coded form and machines for } \\
\text { processing such data, n.e }\end{array}$ & & & \\
\hline 18 & 598 & Miscellaneous chemical products, n.e.s. & $3,055,733,968$ & 1.50 & 47.59 \\
\hline 19 & 772 & $\begin{array}{l}\text { Electrical apparatus for switching or protecting electrical circuits or for making } \\
\text { connections to or in electrical circuits; electrical resistors, other than heating resistors; } \\
\text { printed boar }\end{array}$ & $2,969,980,529$ & 1.45 & 49.04 \\
\hline 20 & 782 & Motor vehicles for the transport of goods and special purpose motor vehicles & $2,875,744,775$ & 1.41 & 50.45 \\
\hline \multirow[t]{2}{*}{21} & & All Others & $101,143,055,026$ & 49.55 & 100.00 \\
\hline & & Total & $204,132,970,801$ & & \\
\hline
\end{tabular}

Source: KRA and Authors' Computation

Table A3. African Countries that have signed or no signed an EPA.

\begin{tabular}{|c|c|c|c|}
\hline $\begin{array}{l}\text { Negotiating } \\
\text { Region }\end{array}$ & $\begin{array}{l}\text { LDCs and non-LDCs that have signed an } \\
\text { EPA }\end{array}$ & $\begin{array}{l}\text { LDCs that have not signed an EPA (export to } \\
\text { EU under EBA or Market Access Regulation } \\
\text { (MAR 1528/2007) }\end{array}$ & $\begin{array}{l}\text { Non-LDCs that have not signed } \\
\text { an EPA }\end{array}$ \\
\hline Central Africa & $\begin{array}{l}\text { Cameroon (Signed on } 26 \text { November 2008; } \\
\text { exports to EU under MAR 1528/2007) }\end{array}$ & $\begin{array}{l}\text { Central African Rep., DR Congo, Chad, } \\
\text { Equatorial Guinea, Sao Tome }\end{array}$ & Gabon (MFN), Rep. Congo (GSP) \\
\hline $\begin{array}{l}\text { East African } \\
\text { Community }\end{array}$ & Signed in October 2014 & Burundi, Rwanda, Tanzania, Uganda - initialed & $\begin{array}{l}\text { Kenya - initialed (exports to EU } \\
\text { under MAR 1528/2007) }\end{array}$ \\
\hline $\begin{array}{l}\text { Eastern and } \\
\text { Southern Africa } \\
\text { (ESA) }\end{array}$ & $\begin{array}{l}\text { Mauritius, Seychelles, Zimbabwe, } \\
\text { Madagascar (All above have signed on } 29 \\
\text { Aug 2009; Exports to EU under EPA) }\end{array}$ & $\begin{array}{l}\text { Djibouti, Eritrea, Ethiopia, Malawi, Somalia, } \\
\text { Sudan Comoros, Zambia - initialed }\end{array}$ & \\
\hline West Africa & $\begin{array}{l}\text { Cote d'Ivoire (Signed on } 26 \text { Nov 2008; } \\
\text { Exports to EU under MAR 1528/2007) }\end{array}$ & $\begin{array}{l}\text { Benin, Burkina Faso, The Gambia, Guinea, } \\
\text { Guinea Bissau, Liberia, Mali, Mauritania, } \\
\text { Niger, Senegal, Sierra Leone, Togo }\end{array}$ & $\begin{array}{l}\text { Ghana - initialed (exports to EU } \\
\text { under MAR 1528/2007) Nigeria } \\
\text { (GSP) Cape Verde (GSP+) }\end{array}$ \\
\hline SADC & $\begin{array}{l}\text { Botswana, Swaziland, Lesotho (Signed on } 4 \\
\text { June 2009), Mozambique (Signed on } 15 \text { June } \\
\text { 2009) (All export to EU under MAR } \\
\text { 1528/2007) }\end{array}$ & Angola & $\begin{array}{l}\text { Namibia - initialed (exports to EU } \\
\text { under MAR 1528/2007) }\end{array}$ \\
\hline
\end{tabular}

Source: European Parliament, 2014

Source: KRA 2013 Data

\section{References}

[1] Baldwin R (1993). A Domino Theory of Regionalism, NBER Working Paper No. 4465NBER Program.

[2] Berisha-Krasniqi, et al. (2008). Economic Partnership Agreements between the European Union and African, Caribbean, and Pacific Countries: What is at Stake for Senegal? IFPRI Discussion Paper No. 765.

[3] Bhagwati, J. (1971). Trade-Diverting Customs Unions and Welfare-Improvement: A Clarification. The Economic Journal, 81: 580-587.

[4] Bhagwati, J. and Panagariya, A. (1996). The Theory of Preferential Trade Agreements: Historical Evolution and Current Trend. The American Economic Review, 86: 82-87.

[5] Fontagne, et al. (2008). An Implication Study of the EU-ACP Economic Partnership Agreements (EPAs) in the Six ACP Regions. The Commission of the European Commission.

[6] Karingi, S. Lang R, Oulmane N, Perez R, Mustapha S and HammoudaH. (2005).

[7] Economic and Welfare Impacts of the EU-Africa Economic Partnership Agreements. ATCP Work paper No. 10.

[8] Keck, A. and Piermartini. (2005). The Economic Impact of EPAs in SADC Countries. WTO Staff Working Paper No. 4.
[9] KIPPRA. (2005). Assessment of the Potential Impact of Economic Partnership Agreements (EPAs) on the Kenyan Economy. A Study by KIPPRA on behalf of Ministry of Trade and Industry.

[10] Lipsey, R. G. (1957). The theory of Custom Unions: Trade Diversion and Welfare. Economica, Vol. 24, No. 93: 40-87.

[11] Milner, C. (2002). Some Simple Analytics of the Trade and Welfare Effects of Economic Partnership Agreements: The Case of the EU-EAC. Mimeo, CREDIT, University of Nottingham.

[12] Milner, C. Oliver Morrissey, O. and McKay A. (2005). Some Simple Analytics of the Trade and Welfare Effects of Economic Partnership Agreements. Journal of African Economies, 14 (3), 327-358.

[13] Mkenda, B. and Hangi, M. (2009). Revenue Implications of EPA on Tanzania. CUTS GRC Publications Series.

[14] Morrissey, O. and Zgovu, E. (2009). The Impact of Economic Partnership Agreements on ACP Agriculture Imports and Welfare. Centre for Research in Economic Development and International Trade (CREDIT), University of Nottingham, CREDIT Research Paper, No. 7.

[15] Panagariya, A. (1998). Rethinking the New Regionalism. In: Nash, J. and Takas, W. (eds). Trade Policy Reform: Lessons and Implications. Washington DC, World Bank.

[16] Panagariya, A. (2000). Preferential Trade Liberalization: The Traditional Theory and New Developments. Journal of Economic Literature, 38: 287-331. 
[17] Perez, R and Karingi, S. (2006). Will the Economic Partnership Agreements foster Sub-Saharan African Development? Paper presented at the GTAP conference, June, Addis Ababa, Ethiopia.

[18] Rotich, J. (2014). Status of EPA negotiations: A presentation during the National Committee on WTO Bali Package and EPA Negitiations, Merica Hotel 4-8 ${ }^{\text {th }}$ 2014, Nakuru, Kenya.
[19] Viner, J. (1950). The Customs Union Issue. New York: Carnegie Endowment for International Peace.

[20] World Trade Organization. (2011). The WTO and preferential trade agreements: From co-xistence to coherence.

[21] Zouhon-Bi, S. G. and Nielson, L. (2007). ECOWAS-Fiscal Revenue Implications of the Prospective EPA with the EU. World Bank Regional Working Paper Series No. 103. 